\title{
Nitrogen, Potassium, and Protein in Grains From Wheat Grown Under Nitrogen and Potassium Fertilizations in the Brazilian Cerrado
}

\author{
Edna M. Bonfim-Silva ${ }^{1}$, Danityelle C. Freitas ${ }^{1}$, Tonny J. A. Silva ${ }^{1}$, Helon H. F. Sousa ${ }^{1}$, William Fenner ${ }^{2}$ \\ \& Jefferson V. José ${ }^{1}$ \\ ${ }^{1}$ Institute of Agrarian and Technological Sciences, Federal University of Mato Grosso, Cuiabá, Brazil \\ ${ }^{2}$ Faculty of Agronomy and Zootechnic, Federal University of Mato Grosso, Cuiabá, Brazil \\ Correspondence: Edna M. Bonfim-Silva, Institute of Agrarian and Technological Sciences, Federal University of \\ Mato Grosso, Rondonópolis, MT, 5055 Students Avenue, 78.735-901, Brazil. Tel: 55-66-981-323-814. E-mail: \\ embonfim@hotmail.com
}

Received: May 31, 2018

Accepted: June 27, $2018 \quad$ Online Published: August 15, 2018

doi:10.5539/jas.v10n9p292

URL: https://doi.org/10.5539/jas.v10n9p292

\begin{abstract}
Nitrogen is a component of proteins contained in grains and potassium an enzymatic activator in nitrate $\left(\mathrm{NO}_{3}^{-}\right)$ assimilation and contributes to the translocation and storage of plant assimilates. Together they can increase protein contents of wheat grains. This research aimed to evaluate whether the interaction between nitrogen $(\mathrm{N})$ and potassium $(\mathrm{K})$ fertilizations in irrigated wheat in the Cerrado region of the Mato Grosso State increases the content and accumulation of $\mathrm{N}, \mathrm{K}$, and protein in wheat grains. The experiment was carried out in the field for two consecutive years (2014 and 2015) in the Federal University of Mato Grosso. It was designed in randomized blocks in $5^{2}$ fractional factorial, composed of combinations between five doses of each of $\mathrm{N}$ and $\mathrm{K}, 13$ treatments combinations in total with four replicates. After harvest, the grains were dried to determine the contents of $\mathrm{N}, \mathrm{K}$, and protein. The nitrogen content was influenced by nitrogen doses in both years and the accumulation significantly influenced by the nitrogen and potassium doses with an average increase among the years of $55.29 \%$ as a function of the potassium application. Nitrogen influenced the accumulation of potassium only in 2015 with effect for potassium in both years. Although there was no interaction between treatments, the influence of $\mathrm{K}$ on $\mathrm{N}$ absorption was evident. Contents and accumulations of $\mathrm{N}$ and $\mathrm{K}$ and the content of protein in wheat grains are influenced by $\mathrm{N}$ and $\mathrm{K}$ fertilizations.
\end{abstract}

Keywords: $\mathrm{N} \times \mathrm{K}$ interaction, Triticum aestivum L., irrigated wheat, fertilization management

\section{Introduction}

The progressive increase in the population will probably increase the pressure on the natural resources of the planet. In 2100, the global population is expected to reach 12.3 billion (Gerland et al., 2014). Unfortunately, approximately $33 \%$ of the soils in the world are currently degraded (FAO, 2015). Incorporating new production areas is only possible in some countries, aggravating the concern over global food safety. One alternative is to optimize the resources that are being used, increasing the yield per area of the main crops in the world (wheat, corn, rice, soybean), as well as to recover degraded areas with limitations of physical and particularly chemical nature, abandoned for the incorporation of new areas to the production system (Fischer, 2014).

The dynamics of absorption by and interaction between nutrients in the plants has been the object of study for decades (Smith \& Epstein, 1964; Minotti et al., 1968; MacLeod \& Carson, 1969), which did not exhaust the questions on the topic. Currently, there are many studies aiming to better understand the topic to make more efficient the use of the nutrients supplied to crops through fertilizations. For example, in a research testing the concentrations of $\mathrm{N}, \mathrm{P}$ and $\mathrm{K}$ in nutrient solution, it was verified that the higher concentration of $\mathrm{P}$ and $\mathrm{K}$ provides the highest dry matter yields of "Herta" barley (Hordeum distichon) and that potassium seems to have more effect in nitrogen metabolism than phosphorus (MacLeod \& Carson, 1969). The synergism between $\mathrm{N}$ and $\mathrm{S}$ maximizes the qualitative parameters of 14 wheat cultivars grown in New Zealand (Luo et al., 2000). Oosterhuis et al. (2014) show the physiological role of potassium, highlighting the physiological functions that contribute to plant health and increased tolerance to biotic and abiotic stresses with reduced growth and productivity under potassium deficiency in crops. Silva and Trevisam (2015) emphasize the importance of the study of the ionic relations of nutrients, highlighting the interactions of antagonism, inhibition, and synergism 
between nutrients in soil and plant.

In the soil-plant-atmosphere system, the interaction between nutrients occurs in various simultaneous processes, either in the soil through the precipitation of combinations of elements or in the contact between nutrient and plant cell (Novais \& Mello, 2007); or in the plant in the moment of absorption (Fernandes \& Souza, 2006), transport, redistribution and metabolism (Taiz \& Zeiger, 2013).

Among the nutrients which are essential to plant growth and development, nitrogen $(\mathrm{N})$ and potassium $(\mathrm{K})$ are required in largest amounts (Oosterhuis et al., 2014) and there is recognized interaction between them in the processes of absorption, transport and accumulation of both nutrients (Engels \& Kirkby, 2001; Brito et al., 2014; Coskun et al., 2016), significantly influencing the yield and quality of crops.

The geographic distribution of wheat (Triticum aestivum), historically cultivated in regions of temperate climate, has changed with the advances in genetic breeding. Currently, wheat can be cultivated with high yield and grain quality in regions with elevated temperatures, such as the Brazilian Cerrado.

The central region of Brazil, dominated by the Cerrado biome, is one of the last areas which can be incorporated in agriculture (Lopes \& Guilherme, 2016), but that does not occur without environmental damages. One form to mitigate this impact is by perfectly understanding the production process of each crop to obtain high yields with quality, in such a way that the opening of new areas is not imperative to increase the production.

Increasing the agricultural production in the Cerrado was not an easy task, due to the endemic conditions. The region, previously occupied mainly by extensive livestock farming and without improved pastures, has had its landscape changed over the years by the technological progress. Soil correction and management, fertilization, plant breeding, and adaptation of new cultivars are examples of tools used to make productive the region which represents $23 \%$ of the Brazilian territory (Lopes \& Guilherme, 2016).

Since the expression of production traits in wheat depends on both genetic and environmental stimuli (Silva et al., 2015), it is safe to claim that knowledge on crop demand for nutrients and their availability in the soil, among other factors, is essential to promote ideal conditions for full expression of these traits.

This research aimed to assess the effects of combined $\mathrm{N}$ and $\mathrm{K}$ fertilizations in irrigated wheat in the Cerrado region of Mato Grosso on the contents and accumulations of N, K, and protein in the grains.

\section{Materials and Methods}

\subsection{Overview}

The field experiment was conducted in the Federal University of Mato Grosso $\left(16^{\circ} 27^{\prime} \mathrm{S}, 54^{\circ} 34^{\prime} \mathrm{W}, 287 \mathrm{~m}\right.$ of altitude). The climate of the region (Aw) is characterized by high temperatures, dry winter, and rainy summer according to Köppen-Geiger (Kottek et al., 2006). During the evaluation period, mean temperatures were 25.9 and $25.7^{\circ} \mathrm{C}$ for the years 2014 and 2015 , respectively (Figure 1).

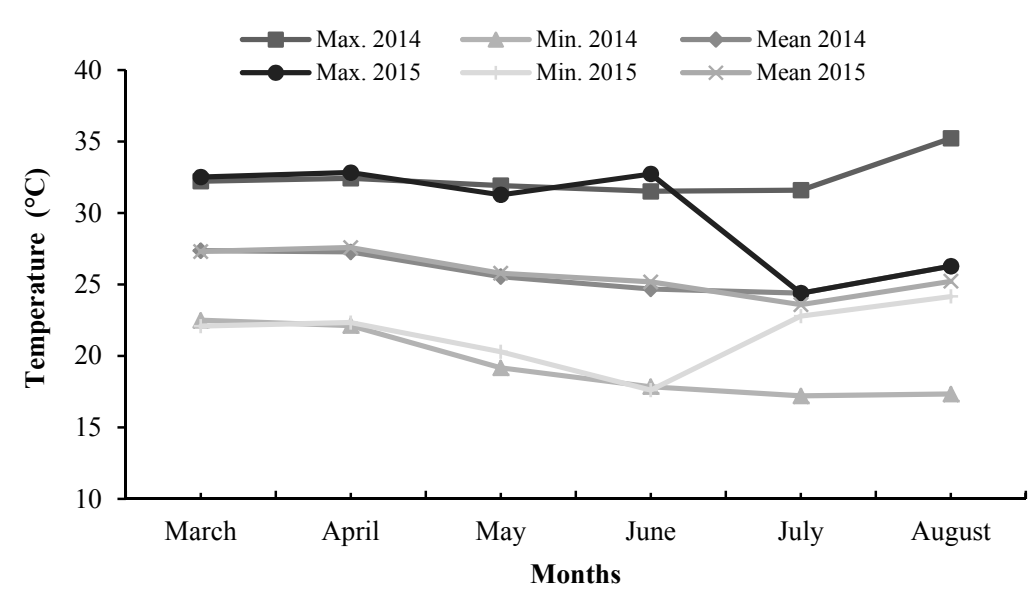

Figure 1. Means values of maximum, minimum and mean temperature along the irrigated wheat cultivation period in the years 2014 and 2015, Rondonópolis-MT, Brazil

The experimental area, previously under native vegetation, has been recently incorporated to the agricultural 
production. The soil of the region, common in rainy tropical regions, is Oxisol (Soil Survey Staff, 2014), characterized by low natural fertility and acid $\mathrm{pH}$ so that its use for agricultural purposes requires acidity correction and supplementation with mineral fertilization. Soil granulometric analysis for the $0-0.2 \mathrm{~m}$ layer showed values of 412.5, 112.5 and $475 \mathrm{~g} \mathrm{~kg}^{-1}$, respectively. Field experiments were carried out for two consecutive years and in each one of them, liming was performed to increase base saturation to $60 \%$. The results of the chemical analysis prior to each cultivation are presented in Table 3.

\subsection{Experimental Design}

The experimental design used in the field was randomized blocks in a $5^{2}$ fractional factorial scheme (Littell \& Mott, 1975), composed of five doses of nitrogen $\left(0,70,140,210\right.$ and $\left.280 \mathrm{~kg} \mathrm{ha}^{-1}\right)$ and five doses of potassium (0, $50,100,150$ and $200 \mathrm{~kg} \mathrm{ha}^{-1}$ ), forming 13 combinations between $\mathrm{N}$ and $\mathrm{K}$ (Table 1) with four replicates, totaling 52 experimental plots.

Table 1. Combination of $\mathrm{N}$ and $\mathrm{K}$ doses $\left(\mathrm{kg} \mathrm{ha}^{-1}\right)^{*}$

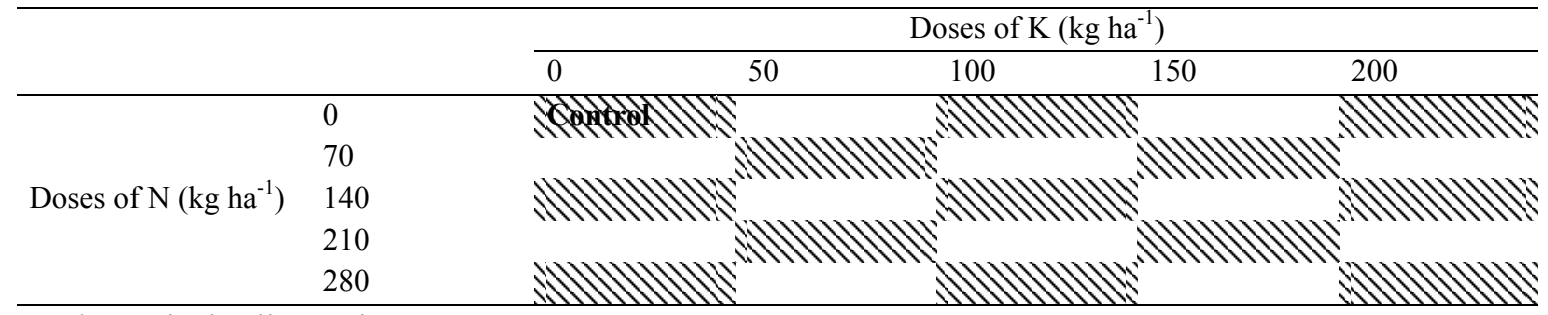

Note. * Hatched cells are the treatments.

Each experimental plot comprised 9 rows with the length of $6.0 \mathrm{~m}$ and spaced by $0.20 \mathrm{~m}$, sown at a density of 350 seeds per $\mathrm{m}^{2}$ with the cultivar BRS 254 (Albrecht et al., 2008). The seven central rows of each experimental plot were used for evaluations, disregarding $0.75 \mathrm{~m}$ on each end, totaling an area of $6.3 \mathrm{~m}^{2}$ (Figure 2).

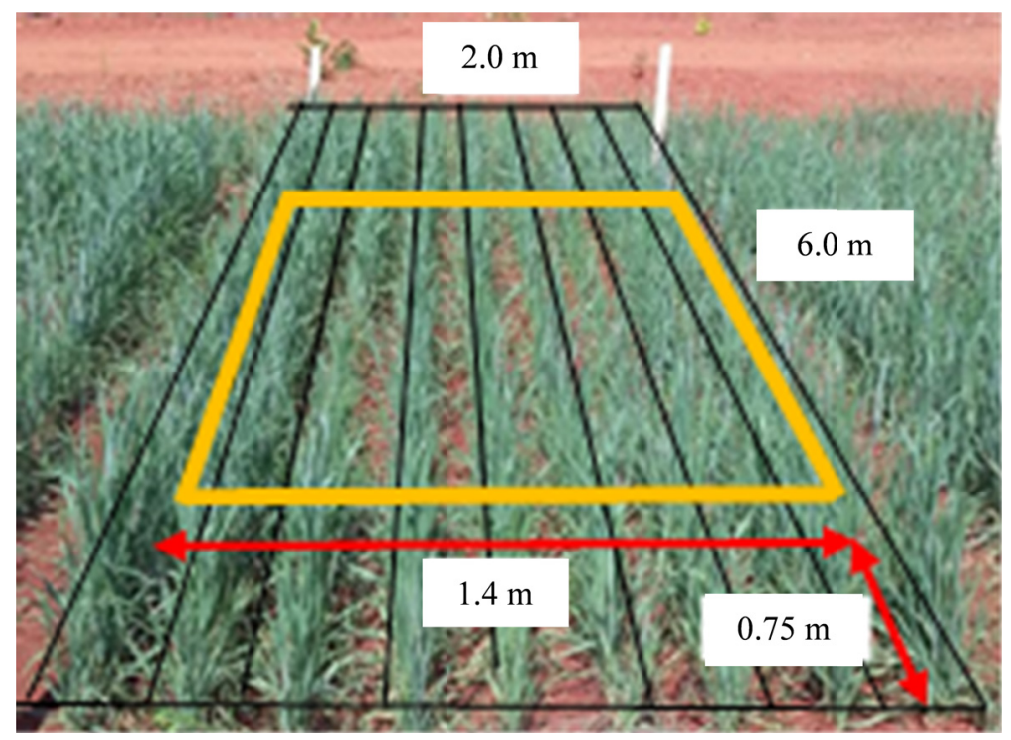

Figure 2. Experimental unit and detail of the evaluation area, Rondonópolis-MT, Brazil

Sowing was performed using the SEMINA II-Wheat Version plot sower (Sattler et al., 2005) and fertilizations were manually applied according to the management presented in Table 2. 
Table 2. Doses, sources and management of applications of nitrogen, phosphorus and potassium in 2014 and 2015, Rondonópolis-MT, Brazil

\begin{tabular}{lllll}
\hline \multirow{2}{*}{ Nutrient } & \multirow{2}{*}{ Dose $\left(\mathrm{kg} \mathrm{ha}^{-1}\right)$} & \multicolumn{2}{c}{ Application splitting $(\%)$} & \multirow{2}{*}{ Source } \\
\cline { 3 - 4 } & $* *$ & 30 & 70 & Urea \\
$\mathrm{N}$ & 200 & 100 & - & SSP \\
$\mathrm{P}\left(\mathrm{P}_{2} \mathrm{O}_{5}\right)$ & $* *$ & 100 & - & KCL \\
$\mathrm{K}\left(\mathrm{K}_{2} \mathrm{O}\right)$ & 50 & 100 & - & FTE BR 12 \\
Micronutrients & & &
\end{tabular}

Note. * Applied 15 days after sowing; ** According to the dose of each treatment; FTE BR12 contains 9\% Zn; $1.8 \% \mathrm{~B} ; 0.8 \% \mathrm{Cu} ; 2 \% \mathrm{Mn} ; 3.5 \% \mathrm{Fe} ; 0.1 \% \mathrm{Mo}$; SSP: single superphosphate; KCL: potassium chloride.

Water deficit estimated using reference evapotranspiration (ETo) and crop evapotranspiration (ETc) (Allen et al., 1998) was based on the data collected at the local agrometeorological station, installed $100 \mathrm{~m}$ away from the experiment. The water deficit was mitigated by application of water through a conventional sprinkler system. The total water volume received by the crop (irrigation + rainfall) corresponded to $498.15 \mathrm{~mm}$ in 2014 and $448.22 \mathrm{~mm}$ in 2015, uniformly distributed along the cycle.

The experiment was carried out until the ideal moisture for grain harvest was achieved (Portela et al., 2011), which occurred at 93 and 108 days after sowing in 2014 and 2015, respectively. Harvest was performed by collecting plants from the evaluation area with manual tools and then separating the grains. Subsequently, grain samples were collected in each treatment (a simple sample of the total grains harvested in the plot), dried in an oven at a mean temperature of $65^{\circ} \mathrm{C}$ until constant weight and processed in a Wiley type mill with $1 \mathrm{~mm}$ thick sieves, being necessary 100 and $500 \mathrm{mg}$ of ground material for nitrogen and potassium analysis, respectively. After that, the contents of total nitrogen and crude protein were determined by the Semi-micro-Kjeldahl method, whereas potassium contents were determined by flame photometry (Malavolta, 1997).

\subsection{Statistical Analysis}

The results were subjected to analysis of variance by $\mathrm{F}$ test and polynomial regression (response surface) for the interaction between $\mathrm{N}$ and $\mathrm{K}$ doses. In case of no significant interaction, first- and second-order regression analyses were carried out using the program Statistical Analysis System (SAS, 2002) at 0.05 probability, except for $\mathrm{N}$ and protein contents in the second year, evaluated at 0.1 probability.

\section{Results}

Nitrogen and potassium had a different influence on the evaluated characteristics, with no significance for interaction between both in the two evaluation years. It is verified a greater influence of nitrogen and potassium in the accumulation of nitrogen in both years of evaluation. Table 3 presents the summary of the analysis of variance of the data with the mean squares, the mean of each variable and the coefficient of variation. 
Table 3. Summary of the analysis of variance for the variables tested

\begin{tabular}{|c|c|c|c|c|c|}
\hline \multirow{2}{*}{ Source of variation } & \multicolumn{5}{|c|}{ Mean square } \\
\hline & $\mathrm{NC}$ & $\mathrm{KC}$ & NA & KA & $\mathrm{PC}$ \\
\hline \multicolumn{6}{|l|}{2014} \\
\hline Nitrogen $(\mathrm{N})$ & $34.24 * *$ & $4.21^{\mathrm{ns}}$ & $55.77 * * *$ & $13.75 * *$ & $1337.37 * *$ \\
\hline Potassium (k) & $17.46^{\mathrm{ns}}$ & $0.58^{\mathrm{ns}}$ & $66.85^{* * *}$ & $13.25^{* *}$ & $682.26^{\mathrm{ns}}$ \\
\hline Block & 14.77 & 14.33 & 66.50 & 15.76 & 576.94 \\
\hline $\mathrm{N} \times \mathrm{K}$ & $0.79^{\mathrm{ns}}$ & $0.80^{\mathrm{ns}}$ & $3.35^{\mathrm{ns}}$ & $1.56^{\mathrm{ns}}$ & $31.11^{\mathrm{ns}}$ \\
\hline Average & 18.21 & 6.93 & 9.34 & 3.72 & 113.80 \\
\hline CV (\%) & 16.35 & 18.68 & 31.59 & 41.85 & 16.35 \\
\hline \multicolumn{6}{|l|}{2015} \\
\hline Nitrogen $(\mathrm{N})$ & $65.38 *$ & $1.89^{\mathrm{ns}}$ & $59.82 *$ & $11.58^{\mathrm{ns}}$ & $2554.14 *$ \\
\hline Potassium (k) & $27.44^{\mathrm{ns}}$ & $0.49^{\mathrm{ns}}$ & $199.92 * * *$ & $17.24 *$ & $1072.16^{\mathrm{ns}}$ \\
\hline Block & 14.03 & 2.08 & 25.57 & 5.58 & 548.18 \\
\hline $\mathrm{N} \times \mathrm{K}$ & $59.98^{\mathrm{ns}}$ & $0.26^{\mathrm{ns}}$ & $51.56^{\mathrm{ns}}$ & $12.47^{\mathrm{ns}}$ & $2343.02^{\mathrm{ns}}$ \\
\hline Average & 17.33 & 6.63 & 20.98 & 30.62 & 108.32 \\
\hline $\mathrm{CV}(\%)$ & 29.39 & 16.33 & 23.39 & 8.34 & 29.39 \\
\hline
\end{tabular}

Note. ${ }^{*}, * *, * * *$ significant at $0.05,0.01$ and $0.0001 \%$ of probability, respectively; ${ }^{\text {ns }}$ not significant, NC: nitrogen content; KC: potassium content; NA: nitrogen accumulation; KA: potassium accumulation; PC: protein content.

After two years of cultivation, there is an improvement in the chemical quality of the soil. The higher soil $\mathrm{pH}$, as well as $\mathrm{Ca}$ and $\mathrm{Mg}$ contents and toxic $\mathrm{Al}$ correction, tend to provide better development of the wheat crop. It is also evidenced that soil K levels, even at the lower nutrient levels, have favored soil level elevation (Table 4).

Table 4. Chemical analyses of the $0-0.2 \mathrm{~m}$ layer of the Oxisol collected in the experimental area (Rondonópolis-MT, Brazil, 2014 and 2015)

\begin{tabular}{|c|c|c|c|c|c|c|c|c|c|c|c|c|c|c|c|}
\hline Treat. & $\mathrm{pH}$ & $\mathrm{Ca}$ & $\mathrm{Mg}$ & $\mathrm{Al}$ & CEC & O.M. & $P$ & $\mathrm{~K}$ & $\mathrm{Zn}$ & $\mathrm{Cu}$ & $\mathrm{Fe}$ & $\mathrm{Mn}$ & B & $\mathrm{S}$ & $\mathrm{V}$ \\
\hline - & $\mathrm{CaCl}_{2}$ & \multirow{2}{*}{\multicolumn{4}{|c|}{ 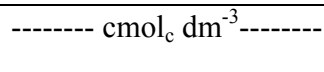 }} & $\mathrm{g} \mathrm{kg}^{-1}$ & \multicolumn{8}{|c|}{ 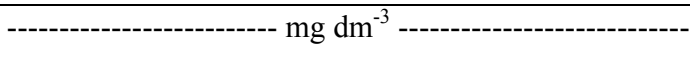 } & \multirow[t]{2}{*}{$--\%$} \\
\hline 2014 & & & & & & & & & & & & & & & \\
\hline - & 4.0 & 0.4 & 0.1 & 1.3 & 7.6 & 18.7 & 3.4 & 52.0 & 0.5 & 0.9 & 122.5 & 19.0 & 0.1 & 6.0 & 8.3 \\
\hline \multicolumn{16}{|l|}{2015} \\
\hline $0 / 0$ & 5.5 & 2.7 & 1.0 & 0.0 & 6.5 & 27.1 & 10.0 & 64.7 & - & - & - & - & - & - & 58.8 \\
\hline $0 / 100$ & 5.2 & 2.0 & 0.8 & 0.0 & 5.9 & 22.7 & 4.2 & 55.5 & - & - & - & - & - & - & 50.2 \\
\hline $0 / 200$ & 5.0 & 1.6 & 0.7 & 0.0 & 5.8 & 21.3 & 6.8 & 88.1 & - & - & - & - & - & - & 43.0 \\
\hline $70 / 50$ & 5.4 & 2.2 & 0.9 & 0.0 & 6.0 & 22.7 & 5.3 & 44.4 & - & - & - & - & - & - & 54.0 \\
\hline $70 / 150$ & 5.6 & 2.8 & 1.1 & 0.0 & 6.1 & 24.1 & 8.7 & 70.7 & - & - & - & - & - & - & 66.0 \\
\hline 140/0 & 5.2 & 2.3 & 0.9 & 0.0 & 6.6 & 27.9 & 10.0 & 38.0 & - & - & - & - & - & - & 49.7 \\
\hline $140 / 100$ & 5.8 & 3.3 & 1.2 & 0.0 & 6.6 & 27.1 & 7.2 & 84.9 & - & - & - & - & - & - & 70.7 \\
\hline $140 / 200$ & 5.0 & 1.8 & 0.7 & 0.0 & 6.1 & 24.1 & 4.9 & 75.1 & - & - & - & - & - & - & 43.6 \\
\hline $210 / 50$ & 5.6 & 3.0 & 1.1 & 0.0 & 6.9 & 27.9 & 15.0 & 90.0 & - & - & - & - & - & - & 62.5 \\
\hline $210 / 150$ & 5.2 & 2.6 & 1.0 & 0.0 & 7.5 & 29.5 & 14.5 & 104.3 & - & - & - & - & - & - & 51.3 \\
\hline $280 / 0$ & 5.3 & 2.9 & 1.1 & 0.0 & 7.7 & 31.2 & 15.0 & 61.0 & - & - & - & - & - & - & 53.2 \\
\hline $280 / 100$ & 5.5 & 2.6 & 1.0 & 0.0 & 6.6 & 28.7 & 5.7 & 67.7 & - & - & - & - & - & - & 56.4 \\
\hline $280 / 200$ & 4.8 & 1.8 & 0.7 & 0.0 & 6.8 & 27.9 & 15.0 & 76.2 & - & - & - & - & - & - & 40.0 \\
\hline
\end{tabular}

\subsection{Nitrogen Content}

Nitrogen doses significantly influenced $\mathrm{N}$ contents in wheat grains, and the data fitted to quadratic and linear regression models in the first and second year, respectively (Figure 3). On the other hand, K fertilization did not influence $\mathrm{N}$ content in wheat grains in any of the years. The lowest $\mathrm{N}$ content in the grains in the first year of cultivation was caused by the $\mathrm{N}$ dose of $159 \mathrm{~kg} \mathrm{ha}^{-1}$, representing a decrease of $4 \%$ in relation to the absence of 
fertilization. In the second year, the increase in the content in response to $\mathrm{N}$ application was equal to $13.64 \%$ of the control for the highest $\mathrm{N}$ dose $\left(280 \mathrm{~kg} \mathrm{ha}^{-1}\right)$. Mean $\mathrm{N}$ contents in wheat grains were 18.02 (\% of the control) and $17.41 \mathrm{~g} \mathrm{~kg}^{-1}$ (\% of the control) for the first and second years of cultivation, respectively.

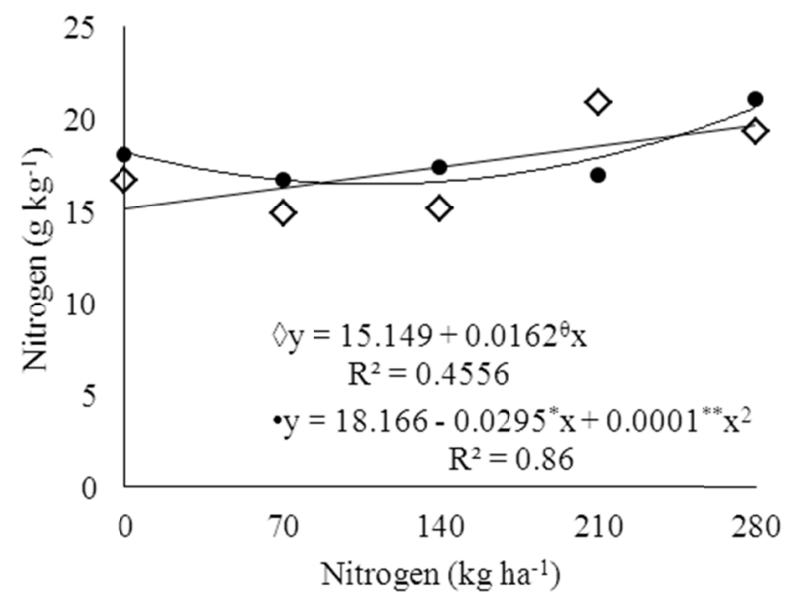

Figure 3. The nitrogen content in BRS 254 wheat grains as a function of nitrogen doses in the first $(\bullet)$ and second $(\diamond)$ years of cultivation in the Cerrado region of Mato Grosso. Rondonópolis-MT, Brazil

Note. * significant at 0.05 probability, ${ }^{* *}$ significant at 0.01 probability, $\theta$ significant at 0.1 .

\subsection{Nitrogen Accumulation}

Nitrogen accumulation as a function of $\mathrm{N}$ application fitted to a quadratic regression model in the first year and to a linear model in the second year (Figure 4A). $\mathrm{N}$ accumulation increased up to the application of $130.50 \mathrm{~kg} \mathrm{ha}^{-1}$ of $\mathrm{N}$, which represents $31.32 \%$ increase in comparison to the control fertilization in the first year of evaluation. The increase in the response to $\mathrm{N}$ application was equal to $21.78 \%$ for the second year. Considering the $\mathrm{N}$ accumulation in response to $\mathrm{K}$ doses, the same trend was observed as for the $\mathrm{N}$ application, that is, they presented similar adjustments in both evaluated year. The data fitted to quadratic and linear regression models for the first and second years of evaluation, respectively (Figure 4B). N accumulation was positively correlated to $\mathrm{K}$ application up to the dose of $145 \mathrm{~kg} \mathrm{ha}^{-1}$ in the first year of evaluation. The increments were 53.78 and $25.43 \%$ for the first and second years so that the mean increment between the years was $55.29 \%$, comparing the average accumulation between the years.
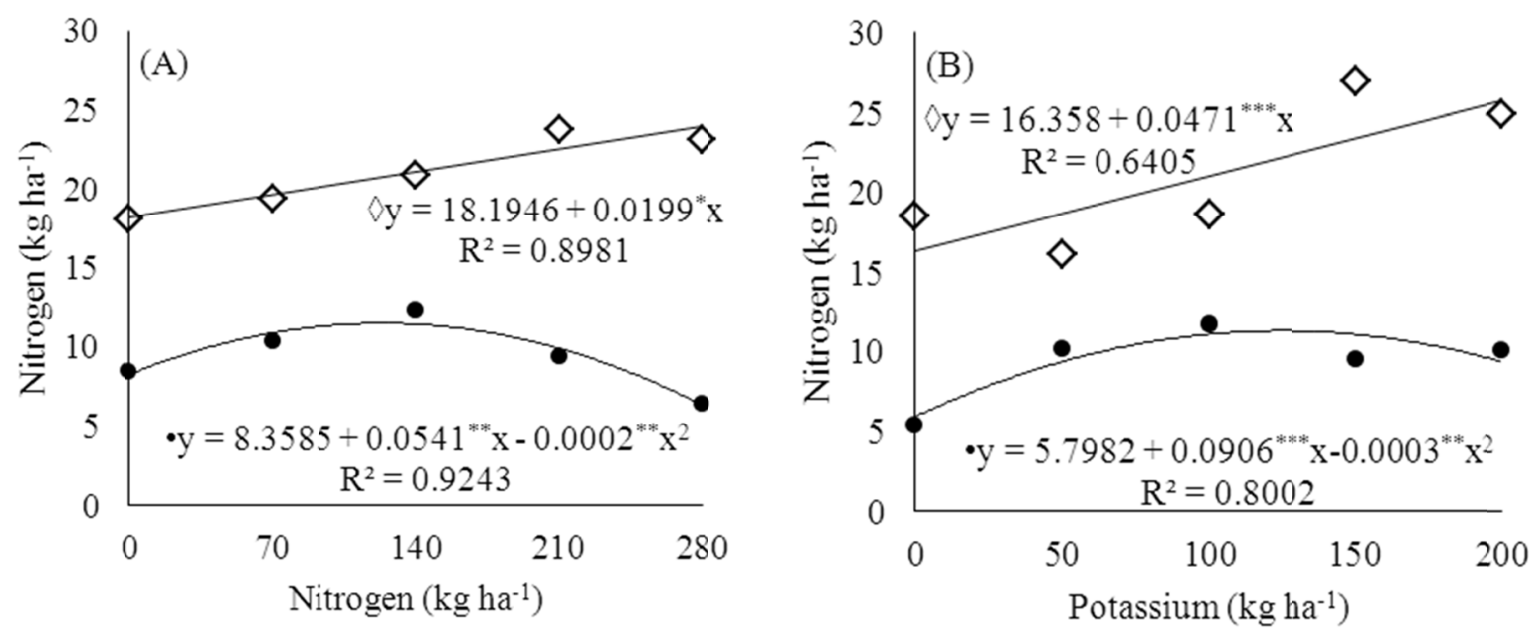

Figure 4. Nitrogen accumulation in BRS 254 wheat grains as a function of nitrogen doses (A) and potassium doses (B) in $2014(\bullet)$ and $2015(\diamond)$

Note. $*$ significant at 0.05 probability, ${ }^{* *}$ significant at 0.05 probability, $* * *$ significant at 0.001 probability. 


\subsection{Potassium Accumulation}

The treatments individually influenced $\mathrm{K}$ accumulation in wheat grains in the first and second years of evaluation. $\mathrm{K}$ accumulation in wheat grains in response to $\mathrm{N}$ fertilization was described by a quadratic regression model (Figure 5A) in the first year. The response to $\mathrm{N}$ application was positive up to the dose of $121 \mathrm{~kg} \mathrm{ha}^{-1}$, which led to an increase of $28.66 \%$. Quadratic and linear regression models fitted to K accumulation in response to the application of $\mathrm{KCl}$ (Figure $5 \mathrm{~B}$ ). $\mathrm{K}$ application led to increments of $58.12 \%$ in the first year up to the dose of $99 \mathrm{~kg} \mathrm{ha}^{-1}$, and $26.12 \%$ in the second year at $200 \mathrm{~kg} \mathrm{ha}^{-1}$.
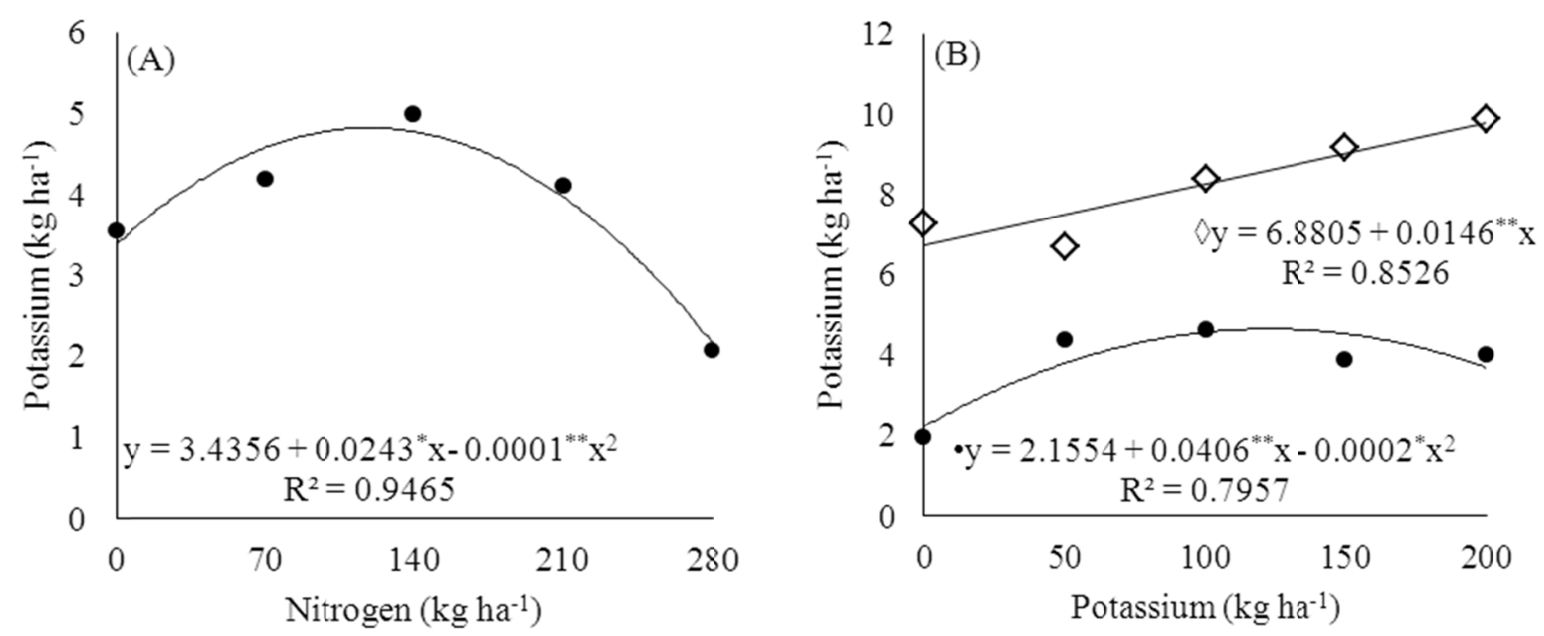

Figure 5. Potassium accumulation in BRS 254 wheat grains as a function of nitrogen doses (A) in the first year and potassium doses in $2014(\bullet)$ and $2015(\diamond)$

Note. $*$ significant at 0.05 probability, $* *$ significant at 0.05 probability, $* * *$ significant at 0.001 probability.

\subsection{Protein Content}

As observed for the $\mathrm{N}$ content, crude protein contents in the grains fitted to a quadratic regression model in the first year and to a linear model in the second year (Figure 6) as a function of N application, with no significance for $\mathrm{K}$ fertilization. The $\mathrm{N}$ dose which led to the lowest content of crude protein in wheat grains in the first year of cultivation was $110 \mathrm{~kg} \mathrm{ha}^{-1}$. In the second year, $\mathrm{N}$ application increased the protein content in wheat grains by $13.64 \%$. Considering the mean values for $\mathrm{N}$ and crude protein contents in wheat grains, there was a mean reduction of $3.39 \%$ from the first to the second year of evaluation.

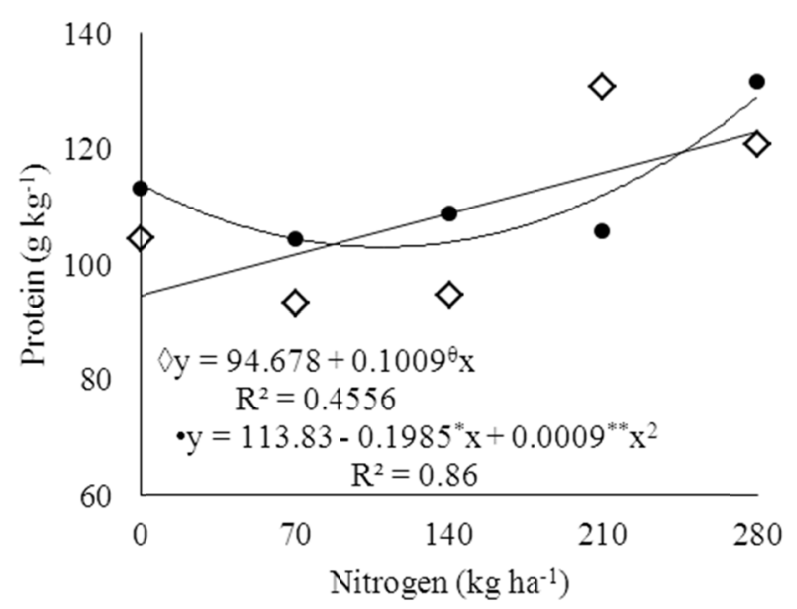

Figure 6. Protein content in BRS 254 wheat grains as a function of nitrogen doses in the first $(\bullet)$ and second $(\diamond)$ years

Note. ${ }^{*}$ significant at 0.05 probability ** significant at 0.01 probability, $\theta$ significant at 0.1 probability. 


\section{Discussion}

\subsection{Nitrogen Content}

Although in the first year the effect was described by a quadratic model, linear responses of $\mathrm{N}$ and protein contents in the grains to increasing $\mathrm{N}$ doses seem to be a rule, because the increase in yield requires a greater supply of the nutrient. A study conducted in Ukraine in a Chernozem (soil with high natural fertility) found protein contents in wheat grains of 13.2 and $25.8 \%$ at the maximum $\mathrm{N}$ dose of $180 \mathrm{~kg} \mathrm{ha}^{-1}$, and $\mathrm{K}$ doses did not significantly influence grain quality (Polevoy et al., 2015).

Considering that the area has been recently incorporated to the agricultural production and that the natural soil $\mathrm{pH}$ was corrected to ideal levels for cultivation, the mineralization of $\mathrm{N}$ from the organic matter may have been accelerated so that it increased $\mathrm{N}$ availability to plants and favored crop response to $\mathrm{N}$ fertilization.

A study on development, production, and nutrition of wheat fertilized with $\mathrm{N}$ and $\mathrm{K}$ under controlled conditions also found no significant interaction between these nutrients, but $\mathrm{N}$ had an individual effect on $\mathrm{K}$ accumulation in the grains, which fitted to a quadratic regression model (Carvalho et al., 2016).

Studies on tracer isotopes in agricultural soils demonstrate that soil $\mathrm{N}$ mineralization provides most of the $\mathrm{N}$ absorbed by plants (Brady \& Weil, 2013). The increase in $\mathrm{N}$ content in the grains is partially due to the greater availability of $\mathrm{N}$ in the soil, from the $\mathrm{N}$ mineralization combined with the applied doses, which consequently led to greater translocation to the grains (Espindula et al., 2010).

As the supply of a nutrient increases substantially, the yield increases up to a point in which the increments of yield and accumulation do not respond at the same rate as the increase in fertilization. Consequently, other factors, of meteorological, edaphic or genetic nature, become limiting to growth and development, or even the supply of another nutrient (Marschner, 2012). This effect is commonly observed with $\mathrm{N}$ because, although it is highly required by crops, fertilizations with high doses do not always correspond with the same proportionality.

The wheat crop absorbs and accumulates most of the $\mathrm{N}$ needed until the early flowering, justifying the split fertilization in the vegetative stage to promote maximum $\mathrm{N}$ absorption and accumulation. If that does not occur, foliar application of $\mathrm{N}$ close to flowering has increased the crude protein content in the grains (Marschner, 2012).

Managements for high yield, with greater N supply, require extra attention to guarantee the demand of the crop for other nutrients because there is a positive correlation between nitrogen and potassium, sulfur, calcium, magnesium, iron, zinc, and copper, which may result in reduction of yield and grain quality. Nitrogen positively influences the accumulation of macro- and micronutrients in the biomass, except phosphorus, manganese, and boron. Conversely, sulfur and iron contents increase in wheat grains with the increase in N, whereas $\mathrm{K}$ content decreases (Hamnér et al., 2017).

Enzymes involved in nitrate $\left(\mathrm{NO}_{3}{ }^{-}\right)$assimilation such as nitrate reductase, glutamine synthetase, and glutamate synthetase had reduced activity under $\mathrm{K}$ deficiency in cotton, whereas the soluble protein content decreased due to the higher activity of protease and peptidase ( $\mathrm{Hu}$ et al., 2016). Although indirectly, $\mathrm{K}$ influences $\mathrm{N}$ assimilation, reducing crop yield.

Nitrogen, a natural component of the amine group, plays a key role in the protein content of the grains, particularly albumins and globulins (Coskun et al., 2016). Nitrogen is fundamental to determine the quality of the product produced from grains of wheat, the main cereal whose storage proteins can form gluten mesh with unique properties of elasticity and strength to produce sourdough bread (Cruz \& Koblitz, 2011).

\subsection{Nitrogen Accumulation}

Nitrogen and potassium fertilizations individually influenced $\mathrm{N}$ accumulation in both years of evaluation. A substantial part of the nutrients accumulated in the grains originates from the remobilization from other vegetative parts of the plants. In wheat, the percentage of $\mathrm{N}$ reallocated to the grains reaches $90 \%$, thus all other plant parts work as a source and the grains as a sink of nutrients (Kong et al., 2016). Considering that and comparing it with different amounts of $\mathrm{N}$ applied, the efficiency of recovery of the applied $\mathrm{N}$ by the crop does not seem to be high.

$\mathrm{N}$ absorption is influenced by the presence of $\mathrm{K}$ because the pathways through which these elements are transported and used by plants significantly overlap, including the influences exerted by $\mathrm{K}$ ions on $\mathrm{N}$ nutrition and physiology, and vice versa (Kong et al., 2016).

$\mathrm{N}$ accumulation in wheat grains in response to $\mathrm{N}$ and $\mathrm{K}$ applications increased substantially from the first to the second year, especially for the highest doses of $\mathrm{N}$ and K. Since the natural fertility of the soil is low, the increments in contents and accumulations of the nutrients in the wheat grains are believed to increase in the long 
term, following the building of soil fertility.

Besides being a cellular osmotic activator and regulator, $\mathrm{K}$ plays a fundamental role in the transport of sucrose to the phloem at high apoplastic $\mathrm{pH}$, at which the transport of this element to the phloem is reduced due to the decrease in the potential gradient $\left(\mathrm{H}^{+}\right)$. At high apoplastic $\mathrm{pH}, \mathrm{K}$ can transport sucrose by reducing the electrochemical gradient, which results in the extrusion of $\mathrm{H}^{+}$, re-establishing the $\mathrm{H}^{+}$-ATPase (Mengel et al., 2001).

Results obtained in studies on winter wheat as a function of the response to $\mathrm{K}$ fertilization in Luvisol in the North China Plain, with three levels of $\mathrm{K}$ fertilization and two levels of production practices, conventional and high yielding, also diverged from the results found in the present study; the authors observed that increments in $\mathrm{K}$ doses significantly increased $\mathrm{K}$ content in the grains (Niu et al., 2013).

\subsection{Potassium Accumulation}

$\mathrm{K}$ accumulation as a function of $\mathrm{N}$ application in the first year was higher than that caused by $\mathrm{K}$ application. The mean difference is $6.79 \%$ between the $\mathrm{N}$ and $\mathrm{K}$ doses which caused highest $\mathrm{K}$ accumulation. This demonstrates that other factors, besides the availability of nutrients, influence absorption, assimilation, and translocation. This effect of $\mathrm{N}$ on $\mathrm{K}$ accumulation has also been reported in a study testing the interaction between $\mathrm{N}$ and $\mathrm{K}$ in a protected environment (Carvalho et al., 2016).

$\mathrm{K}$ is an enzymatic activator and participates in the translocation and storage of assimilates, being a highly dynamic nutrient in the soil-plant system. In addition, it is fundamental for the maintenance of the osmotic equilibrium in plants, acting directly on stomatal opening and closure, with a key role in the tolerance to biotic and abiotic stresses (Meurer, 2006; Renade-Malvi, 2011). These characteristics allow the maintenance of transpiration rates and, consequently, the absorption of water and nutrients.

The mean distribution of $\mathrm{K}$ in wheat plants is $2 \%$ in the roots, $72 \%$ in the shoots, $11 \%$ in the grains, and $15 \%$ in the straw. K does not tend to be remobilized from the other tissues to the grains, and its highest content is found in the shoots. Conversely, more than $70 \%$ of the total $\mathrm{N}$ absorbed is translocated to the grains, associated with their protein content (Fageria et al., 2011).

In this context, it is worth highlighting that the interaction between $\mathrm{N}$ and $\mathrm{K}$ occurs in a dynamic manner and is influenced by various factors which act simultaneously, such as the form of $\mathrm{N}$ supply, levels of $\mathrm{N}$ and $\mathrm{K}$ in the soil, soil texture and environmental conditions. Even if adequate supplies of $\mathrm{N}$ and $\mathrm{K}$ result in increments in yield, quality and resistance to biotic and abiotic stresses, the above-mentioned factors may lead to the absence of significant interaction by synergism between the nutrients, although the interaction between them was evident (Zhang et al., 2010).

In a study evaluating $\mathrm{K}$ dynamics in the soil and in the plant under mineral and organic fertilization with 30 years of evaluation in soils of the United Kingdom, Germany and Poland, researchers observed recovery rates of $\mathrm{K}$ from mineral fertilizer by the crops of up to $62 \%$. Soils in which a greater fraction of the CEC was related to the organic matter led to the higher efficiency of mineral fertilization compared with those with a CEC related to soil colloids (Blake et al., 1999).

Besides fertilization management, the production system has great influence on the yield. A study in Northeast China evaluating grain yield under different production practices and soil fertility levels found, through meta-analysis, that mulch can increase grain yield by more than $13 \%$ in comparison to the conventional cultivation system (Wang et al., 2018). In fact, mulch induced mineralization and mobilization of phosphate improving its availability and uptake by plants

\subsection{Protein Content}

The reduction in protein content up to the $\mathrm{N}$ dose of $140 \mathrm{~kg} \mathrm{ha}^{-1}$ in comparison to the absence of $\mathrm{N}$ fertilization in the first year can be attributed to the higher grain yield and decrease in the mean content of crude protein, as well as to the use in the mineralization of soil organic matter. At higher doses, the $\mathrm{N}$ supplied through fertilization was sufficient to minimize this effect and promote higher protein content in wheat grains. From the second year of evaluation, the response fits the expected pattern, with the linear response for $\mathrm{N}$ and protein contents in wheat grains.

Protein contents increment of approximately $10 \%$ more than the control found in the present study have also been reported in the grains as a result of $\mathrm{N}$ applications $\left(0,40,80\right.$ and $\left.120 \mathrm{~kg} \mathrm{ha}^{-1}\right)$ in wheat with grain protein content around 10\% (Rathore et al., 2017). In a study of the interaction between water depths and N doses (20, $50,100,200$ and $400 \mathrm{~kg} \mathrm{ha}^{-1}$ ) in wheat plants, there was effect of $\mathrm{N}$ on the crude protein content (average of 
$16.7 \%$ ), reaching a maximum at $200 \mathrm{~kg} \mathrm{ha}^{-1}$ of $\mathrm{N}$ (Boschini et al., 2011).

Studies have reported increments in crude protein contents in wheat grains as a function of $\mathrm{N}$ fertilizer applied as top-dressing. Under conditions of low $\mathrm{N}$ availability, plants reduce the synthesis of proteins in the grains, generating grains with low protein contents (Pinnow et al., 2013) and was achieved 12.2\% of crude protein associated to dose of $90 \mathrm{~kg} \mathrm{ha}^{-1}$ of nitrogen applied in sowing and top-dressing of began tillering (Stefen et al., 2014).

A study demonstrated the improvement in the nutritional quality of wheat grains with the application of ammonium sulphate associate with growth regulator, represented by the higher protein content $(11.25 \%$ at 150 $\mathrm{kg} \mathrm{ha}^{-1} \mathrm{de} \mathrm{N}$ ) in the grains despite the reduction in the contents of phosphorus, potassium and manganese, with fit to a linear regression model as a function of the ammonium sulphate doses (Espindula et al., 2010). A higher number of grains produced at the highest doses was pointed as a conditioning factor for the higher $\mathrm{N}$ accumulation and reduction in the contents of phosphorus, potassium, and manganese, although the levels of these nutrients in the soil are considered as adequate.

\section{Conclusion}

The contents and accumulations of nitrogen and potassium and the content of protein in wheat grains are influenced by nitrogen and potassium fertilizations. Although there was no interaction between treatments, the influence of potassium on nitrogen absorption is evident.

\section{Acknowledgements}

The authors express their gratitude to the following organizations for collaborating in the accomplishment of this study: CAPES (Coordination for Improvement of Higher Education Personnel), CNPq (National Council for Scientific and Technological Development), EMBRAPA (Brazilian Agricultural Research Corporation), and FAPEMAT (Research Support Foundation of the State of Mato Grosso).

\section{References}

Albrecht, J. C., Silva, M. S., Scheeren, P. L., Andrade, J. M. V., Trindade, M. G., Sobrinho, J. S., ... Yamanaka, C. H. (2008). BRS 254-Trigo melhorador: Cultivar com alta qualidade industrial para a região do Cerrado. Distrito Federal (DF): Embrapa Cerrados.

Allen, R. G., Pereira, L. S., Raes, D., \& Smith, M. (1998). Crop evapotranspiration: Guidelines for computing crop water requirements. Roma (IT): FAO.

Blake, L., Mercik, S., Koerschens, M., Goulding, K. W. T., Stempen, S., Weigel, A., Poulton, P. R., \& Powlson, D. S. (1999). Potassium content in soil, uptake in plants and the potassium balance in three European long-term field experiments. Plant and Soil, 216, 1-14. https://doi.org/10.1023/A:1004730023746

Boschini, A. P. M., Silva, C. L., Oliveira, C. A. S., Oliveira Júnior, M. P., Miranda, M. Z., \& Fagioli, M. (2011). Aspectos quantitativos e qualitativos do grão de trigo influenciados por nitrogênio e lâminas de água. Revista Brasileira de Engenharia Agrícola e Ambiental, 15, 450-457. https://doi.org/10.1590/S1415-436 62011000500003

Brady, N. C., \& Weil, R. R. (2013). Elementos da natureza e propriedades dos solos: Ciclagem de nutrientes e fertilidade do solo. Rio Grande do Sul (RS): Bookman.

Britto, D. T., Balkos, K.D., Becker, A., Coskun, D., Huynh, W. Q., \& Kronzucker, H. J. (2014). Potassium and nitrogen poising: Physiological changes and biomass gains in rice and barley. Canadian Journal of Plant Science, 94, 1085-1089. https://doi.org/10.4141/cjps2013-143

Carvalho, J. M. G., Bonfim-Silva, E. M., Silva, T. J. A., Sousa, H. H. F., Guimarães, S. L., \& Pacheco, A. B. (2016). Nitrogen and potassium in production, nutrition and water use efficiency in wheat plants. Ciencia $e$ Investigación Agraria, 43, 442-451. https://doi.org/10.4067/S0718-16202016000300010

Coskun, D., Britto, D. T., \& Kronzucker, H. J. (2016). The nitrogen-potassium intersection: Membranes, metabolism, and mechanism. Plant Cell Environment, 100, 1-13. https://doi.org/10.1111/pce.12671

Cruz, R. S., \& Koblitz, M. G. B. (2011). Grãos, cereais e leguminosas. In M. G. B. Koblitz (Ed.), Matérias-primas alimentícias: Composição e controle de qualidade (1st ed., pp. 44-120). Rio de Janeiro (RJ): Guanabara Koogan.

Engels, C., \& Kirkby, E. A. (2001). Cycling of nitrogen and potassium between shoot and roots in maize as affected by shoot and root growth. Journal of Plant Nutrition and Soil Science, 164, 183-191. https://doi.org/10.1002/1522-2624(200104)164:2<183::AID-JPLN183>3.0.CO;2-B 
Espindula, M. C., Campanharo, M., Rocha, V. S., Monnerat, P. R., \& Favarato, L. F. (2010). Composição mineral de grãos de trigo submetidos a doses de sulfato de amônio e trinexapac-etil. Pesquisa Agropecuária Tropical, 40, 513-520. https://doi.org/10.5216/pat.v40i4.6928

Fageria, N. K., Baligar, V. C., \& Jones, C. A. (2011). Growth and mineral nutrition of field crops (3rd ed.). Washington (DC): CRC Press.

Fernandes, M. S., \& Souza, S. R. (2006). Absorção de nutrientes. In M. S. Fernandes (Ed.), Nutrição mineral de plantas (1st ed., pp. 115-152). Minas Gerais (MG): Sociedade Brasileira de Ciência do Solo.

Fischer, T., Byerlee, D., \& Edmeades, G. (2014). Crop yields and global food security. Will yield increase continue to feed the world? Australian (AU): ACIAR.

Food and Agriculture Organization of the United Nations. (2015). Global Soil Resources. Status of the World's Soil Resources. Roma (IT): Main Report 1.

Gerland, P., Raftery, A., Sevcíková, H., Li, N., Gu, D., Spoorenberg, T., ... Wilmoth, J. (2014). World population stabilization unlikely this century. Science, 387, 01-05. https://doi.org/10.1126/science.1257469

Hamnér, K., Weih, M., Eriksson, J., \& Kirchmann, H. (2017). Influence of nitrogen supply on macro- and micronutrient accumulation during growth of winter wheat. Field Crops Research, 213, 118-129. https://doi.org/10.1016/j.fcr.2017.08.002

Hu, W., Zhao, W., Yang, J., Oosterhuis, D. M., Loka, D. A., \& Zhou, Z. (2016). Relationship between potassium fertilization and nitrogen metabolism in the leaf subtending the cotton (Gossypium hirsutum L.) boll during the boll development stage. Plant Physiology and Biochemistry, 101, 113-123. https://doi.org/10.1016/ j.plaphy.2016.01.019

Kong, L., Xie, Y., Hu, L., Feng, B., \& Li, S. (2016). Remobilization of vegetative nitrogen to developing grain in wheat (Triticum aestivum L.). Field Crops Research, 196, 134-144. https://doi.org/10.1016/j.fcr.2016. 06.015

Kottek, M., Grieser, J., Beck, C., Rudolf, B., \& Rubel, F. (2006). World Map of the Köppen-Geiger Climate Classification Updated. Meteorologische Zeitschrif, 15, 259-263. https://doi.org/10.1127/0941-2948/ 2006/0130

Littell, R. C., \& Mott, G. O. (1975). Computer assisted design and analysis of response surface experiments in agronomy. Soil Crop Society Florida Proceedings, 34, 94-97.

Lopes, A. S., \& Guilherme, L. R. G. (2016). A career perspective on soil management in the Cerrado region of Brazil. Advances in Agronomy, 137, 1-72. https://doi.org/10.1016/bs.agron.2015.12.004

Luo, C., Branlard, G., Griffin, W. B., \& Mcneil, D. L. (2000). The effect of nitrogen and sulphur fertilization and their interaction with genotype on wheat glutenin's and quality parameters. Journal of Cereal Science, 31, 185-194. https://doi.org/10.1006/jcrs.1999.0298

MacLeod, L. B., \& Carson, R. B. (1969). Effects of N, P, and K and their interactions on the nitrogen metabolism of vegetative barley tissue and on the chemical composition of grain in hydroponic culture. Agronomy Journal, 61, 275. https://doi.org/10.2134/agronj1969.00021962006100020029x

Malavolta, E. (1997). Avaliação do estado nutricional das plantas: princípios e aplicações. São Paulo (SP): POTAFOS.

Marschner, P. (2012). Marschner's mineral nutrition of higher plants. Japan (JP): Academic Press.

Meurer, E. J. (2006). Potássio. In M. S. Fernandes (Ed.), Nutrição mineral de plantas (1st ed., pp. 281-299). Minas Gerais (MG): Sociedade Brasileira de Ciência do solo.

Minotti, P. L., Williams, D. C., \& Jackson, W. A. (1968). Nitrate uptake and reduction as affected by calcium and potassium. Soil Science Society of America Journal, 32, 692-698. https://doi.org/10.2136/sssaj1968. $03615995003200050032 x$

Niu, J., Zhang, W., Ru, S., Chen, X., Xiao, K., Zhang, X., ... Zhang, F. (2013). Effects of potassium fertilization on winter wheat under different production practices in the north china plain. Field Crops Research, 140, 69-76. https://doi.org/10.1016/j.fcr.2012.10.008

Novais, R. F., Mello, J. W. V. (2007). Relação Solo-Planta. In R. F. Novais, V. H. V. Alvarez, R. L. F. Fontes, R. B. Cantarutti, \& J. C. L. Neves (Eds.), Fertilidade Do Solo (1st ed., pp. 133-204). Minas Gerais (MG):Sociedade Brasileira de Ciência do Solo. 
Oosterhuis, D. M., Loka, D.A., Kawakami, E. M., \& Pettigrew, W, T. (2014). The physiology of potassium in crop production. Advances in Agronomy, 126, 203-233. https://doi.org/10.1016/B978-0-12-800132-5. 00003-1

Pinnow, C., Benin, G., Viola, R., da Silva, C. L., Gutkoski, L. C., \& Cassol, L. C. (2013). Qualidade industrial do trigo em resposta à adubação verde e doses de nitrogênio. Bragantia, 72, 20-28.

Polevoy, V. M., Lukashchuk, L. Y., \& Peskovski, G. (2015). Efficiency of potassium application in relation to nitrogen fertilization level in winter wheat, grain maize, and sugar beet cultivated in western Ukraine. $e$-if $c$, $43,1-11$.

Portela, J. A., Sattler, A., \& Faganello, A. (2011). Tecnologia de colheita de trigo. In J. L. F. Pires, L. Vargas, \& G. R. Cunha (Eds.), Trigo no Brasil (1st ed., pp. 325-348). Rio Grande do Sul (RS): EMBRAPA Trigo.

Ranade-Malvi, U. (2011). Interaction of micronutrients with major nutrients with special reference to potassium. Karnataka Journal of Agricultural Science, 24, 106-109.

Rathore, V. S., Singh, N., Bhardwaj, S., Puthiyedathu, R., Mal, B., Kumar, M., ... Parkash, O. (2017). Yield, water and nitrogen use efficiencies of sprinkler irrigated wheat grown under different irrigation and nitrogen levels in an arid region. Agricultural Water Management, 187, 232-245. https://doi.org/10.1016/j.agwat. 2017.03.031

Sattler, A., Faganello, A., \& Portella, A. (2005). Semeadoras para plantio direto de parcelas experimentais. Rio Grande do Sul (RS): EMBRAPA.

Silva, J. A. G., Arenhardt, E. G., Krüger, C. A. M. B., Lucchese, O. A., Metz, M., \& Marolli, A. (2015). A expressão dos componentes de produtividade do trigo pela classe tecnológica e aproveitamento do nitrogênio. Revista Brasileira de Engenharia Agrícola e Ambiental, 19, 27-33. https://doi.org/10.1590/ 1807-1929/agriambi.v19n1p27-33

Silva, M. L. S., \& Trevizam, A. R. (2015). Interações iônicas e seus efeitos na nutrição das plantas. Informações Agronômicas, 1, 10-16.

Smith, R. C., \& Epstein, E. (1964). Ion absorption by shoot tissue: kinetics of potassium and rubidium absorption by corn leaf tissue. Plant Physiology, 39, 992-996.

Soil Survey Staff. (2014). Keys to Soil Taxonomy. Washington, DC: USDA, Natural Resources Conservation Service.

Statistical Analysis System Institute. (2002). SAS: User's guide: Statistics. North Carolina (NC): SAS.

Stefen, D. L. V., Souza, C. A., Coelho, C. M. M., Tormen, E., Zanesco, P. R., Casa, R. T., ... Nunes, R. (2014). Adubação nitrogenada associada ao emprego de reguladores de crescimento em trigo cv. Mirante. Revista de Ciências Agroveterinárias, 13, 30-39.

Taiz, L., \& Zeiger, E. (2013). Fisiologia vegetal. Rio Grande do Sul (RS): Artmed.

Wang, L., Sun, J., Zhang, Z., Xu, P., \& Shangguan, Z. (2018). Winter wheat grain yield in response to different production practices and soil fertility in northern China. Soil Tillage Research, 176, 10-17. https://doi.org/ 10.1016/j.still.2017.10.001

Zhang, F., Niu, J., Zhang, W., Chen, X., Li, C., Yuan, L., \& Xie, J. (2010). Potassium nutrition of crops under varied regimes of nitrogen supply. Plant and Soil, 335, 21-34. https://doi.org/10.1007/s11104-010-0323-4

\section{Copyrights}

Copyright for this article is retained by the author (s), with first publication rights granted to the journal.

This is an open-access article distributed under the terms and conditions of the Creative Commons Attribution license (http://creativecommons.org/licenses/by/4.0/). 